\title{
Audyt komunikacyjny w badaniu efektywności procesu komunikacji wewnętrznej przedsiębiorstw
}

\author{
Michat Wilczewski*
}

Artykut przedstawia role audytu komunikacyjnego w diagnozowaniu polityki komunikacyjnej przedsiębiorstwa. W tym celu sq wyeksplikowane takie pojęcia $i$ ich teoretyczne implikacje dla podjętego zagadnienia, jak komunikacja w przedsiębiorstwach, strategia komunikacyjna, audyt komunikacyjny i przedmioty jego zainteresowania, metody i procedury zalecane $w$ trakcie przeprowadzania audytu, a także ważniejsze problemy ujawniane w procesie audytowania. Odpowiednia diagnoza $i$ wiedza nt. wad w strategii komunikacyjnej przedsiębiorstwa stanowia warunek konieczny do planowania takiej strategii komunikacyjnej, która będzie znana pracownikom przedsiębiorstwa i przez nich wspierana w taki sposób, aby można byto usprawnić przeptyw informacji wewnatrz firmy.

Słowa kluczowe: audyt komunikacyjny, komunikacja w przedsiębiorstwach, strategia komunikacyjna, badanie komunikacji, komunikacja wewnętrzna.

Nadesłany: 11.05.2014 | Zaakceptowany do druku: 14.09.2014

\section{Communications Audit in Measuring the Effectiveness of Communication Strategies in Companies}

The article presents the role a communications audit plays in diagnosing the current efficacy of a communication policy implemented in a company. To do so, such concepts as well as their theoretical implications are explicated as: corporate communications, communication strategy, communications audit and its subjects of interest, methods and procedures recommended for conducting a communications audit, and major problems revealed in the auditing process. The right diagnosis and knowledge of existing drawbacks in a company's communication strategy is an absolute prerequisite for designing such a strategy which will be known to the employees and supported by them, so that information in the company can be improved.

Keywords: communications audit, corporate communications, communication strategy, measuring communication, internal communication.

Submitted: 11.05.2014 | Accepted: 14.09.2014

JEL: M42

\footnotetext{
Dr Michał Wilczewski - Uniwersytet Warszawski, Wydział Lingwistyki Stosowanej, Instytut Kulturologii i Lingwistyki Antropocentrycznej.

Adres do korespondencji: Uniwersytet Warszawski, Wydział Lingwistyki Stosowanej, ul. Szturmowa 4, pok. 512, 02-678 Warszawa; e-mail: m.wilczewski@uw.edu.pl.
} 


\section{Wprowadzenie}

Badanie komunikacji specjalistycznej w przedsiębiorstwach, instytucjach i organizacjach cieszy się obecnie tak dużym zainteresowaniem, że w ostatnich kilku latach ukształtowała się dyscyplina badawcza o nazwie „komunikacja w przedsiębiorstwach" (corporate communications) (Grucza, 2013, s. 112) czy „komunikacja korporacyjna". Teoretyczna baza pod te dyscyplinę była przez ostatnie dwie dekady tworzona w badaniach nad marketingiem (marketing communication), organizacja i organizowaniem (organisational communication), strategicznym zarządzaniem przedsiębiorstwem czy komunikowaniem (Van Riel, 2003, s. 163).

Relewantną w kontekście przedmiotu naszego zainteresowania jest definicja Van Riela (2003, s. 163; por. też Corenelissen, 2004, s. 27; Balmer i Gray, 2000, s. 257), zgodnie z którą „komunikacja korporacyjna to aranżowanie elementów składających się na tożsamość organizacji (jak komunikacja, symbole i zachowanie członków organizacji) w taki sposób, aby wykreować i podtrzymać pozytywną reputację, wizerunek tej organizacji w oczach wszystkich grup, z którymi organizacja wchodzi w jakieś relacje" (o strategicznej roli komunikacji korporacyjnej w budowaniu reputacji firmy zob. Gray i Balmer, 1998). Tak więc centralnym zagadnieniem w komunikacji korporacyjnej jest implementacja ,strategii tożsamości” (por. Van Riel, 1995, s. 134), która realizuje się w drodze działalności komunikacyjnej zarówno wewnętrznej, jak i zewnętrznej, włączając $w$ to obecnych i potencjalnych klientów oraz ogół społeczeństwa (por. Łompieś, 2014, s. 61). Na tej podstawie można wyodrębnić takie obszary komunikacji korporacyjnej, jak komunikacja zarządzania (management communication), komunikacja marketingowa (marketing communication) oraz komunikacja organizacyjna (organisational communication). Badania w tych trzech obszarach winny prezentować dociekania w kwestii określenia tego, czym jest tożsamość danej firmy, instytucji czy organizacji, jak ją tworzyć, jak wpływa ona na reputację firmy i jak ten wpływ przekłada się na sposób działania firmy, a także jakie są metody budowania i wprowadzania w życie spójnej strategii czy polityki komunikacyjnej firmy.
Nie ulega wątpliwości, że budowanie i wprowadzanie w życie spójnej strategii/ polityki komunikacyjnej jest kluczowe dla funkcjonowania przedsiębiorstwa, bo przekłada sie na wzrost jego potencjału komunikacyjnego, czyli m.in. na wzrost satysfakcji pracowników, a co za tym idzie - na zmniejszenie absencji w pracy i wzrost ich produktywności (por. Clampitt i Downs, 1993). Faktem również jest, że w wielu przedsiębiorstwach rola komunikacji okazuje się być wciąż niedocenianą, czego powodem jest przekonanie pionu kierowniczego, że kluczowe dla efektywnego funkcjonowania firmy jest wypełnianie codziennych obowiązków przez pracowników. Często nie dostrzegają oni wagi proporcjonalnej zależności między wydajnością a komunikacja, co oznacza, że wykonywanie tych codziennych obowiązków wymaga współpracy, której efektywność jest uzależniona od efektywności komunikacji. Trzeba sobie uświadomić, że kierownicy poświęcają aż do $90 \%$ swojego czasu pracy na komunikowanie sie z pracownikami, których nota bene codzienne obowiązki są również osadzone w komunikacji (Alnajjar 2013, s. 9-10). Z tego względu waga efektywności komunikacyjnej winna być doceniona i odzwierciedlona w próbie wypracowania specyficznych strategii komunikacyjnych, mechanizmów ich wdrażania i rozwoju, czemu służy właśnie systematyczne i kompletne badanie wewnętrznych i zewnętrznych działań komunikacyjnych. W tym artykule skupimy się na badaniu komunikacji wewnętrznej.

\section{Istota komunikacji wewnętrznej}

Komunikacja wewnętrzna jest różnie definiowana w literaturze przedmiotu. Bywa rozumiana jako proces, którego celem jest wymiana, przepływ informacji i pomysłów w przedsiębiorstwie (Bovée i Thill, 2000, s. 7; Mazzei, 2010, s. 221); jako jednoczenie poszczególnych jednostek przedsiębiorstwa i samego przedsiębiorstwa z jego środowiskiem zewnętrznym (Gros, 2003, s. 69); jako wspieranie wdrażania strategii, promowania wartości organizacyjnych, budowania osobowości przedsiębiorstwa i przyczynianie się do jego konkurencyjności (Dunmore, 2002, s. 133-134); jako podwyższanie wśród pracowników zrozumienia każdej decyzji podjettej przez kierownictwo przedsiębiorstwa, budowanie 
lojalności i identyfikowania się z organizacją (Olsztyńska, 2002, s. 167) oraz, ogólnie biorąc, jako budowanie wartości przedsiębiorstwa (Quirkie, 2008, s. 21).

Z kolei Cheney i Christensen (2001, s. 233) oraz Scholes (1997, s. xviii) zwracają szczególną uwagę na interakcyjny charakter komunikacji wewnętrznej, gdyż definiują ją jako interakcje pracownicze lub zarządzanie nimi, rozpatrywane w kontekście misji i rozwoju danej organizacji (szczególowo nt. różnych podejść do komunikacji wewnętrznej zob. Rogala i Kaniewska-Sęba, 2013).

Za Rogalą i Kaniewską-Sębą przyjmujemy, że „na zintegrowaną komunikację wewnętrzną składają się formalne i nieformalne akty komunikacji, które odbywają się na wszystkich poziomach organizacji” (2013, s. 10; tłum. - M.W.).

Komunikacja wewnątrz firmy przybiera dwa kierunki: wertykalny (komunikacja „góra - dól” pomiędzy poszczególnymi stopniami hierarchii pracowniczej) oraz horyzontalny (pomiędzy pracownikami na stanowiskach $\mathrm{z}$ tego samego poziomu hierarchii). $\mathrm{O}$ efektywnej komunikacji wewnątrz firmy - ale też właściwie w obrębie każdej organizacji - można mówić wtedy, gdy efektywnie przebiega proces komunikacji między środowiskiem kierowniczym firmy a jej pracownikami, tzn. gdy istnieje zgoda, równowaga pomiędzy komunikacyjnymi wymaganiami a możliwościami ich realizacji. Konieczność wystąpienia takiej zgody wynika bezpośrednio z uzależnienia efektywnej realizacji zadań kierownictwa, do których należą: planowanie, organizowanie, motywowanie i kontrola (Ober, 2013, s. 258), od komunikowania, jako że wymagają one od kierowników utrzymywania kontaktów, wymiany informacji z przełożonymi, pracownikami i organizacjami zewnętrznymi (Jung-Konstanty, 2013, s. 172).

Praktycznie w każdej firmie można natrafić na bariery komunikacyjne, wynikające $\mathrm{z}$ różnych powodów, którymi są np. rywalizacja pomiędzy poszczególnymi szczeblami hierarchii pracowniczej. Idealnym stanem jest taki, gdy stosunki pomiędzy podwładnymi a przełożonymi opierają się na zaufaniu i kierują nimi cele wspólne, oscylujące wokół dobra firmy czy organizacji, bo jak trafnie ujmują to autorzy badania zaangażowania pracowników w procesy decyzyjne firmy: ,jeśli zbudujemy zespół, którego członkowie będą sobie ufać, to będą się również dobrze ze sobą komunikować; jeśli rozwiniemy wśród nich postawy sprzyjające kooperacji, odpowiednie umiejętności pojawią się samoistnie" (Deetz i Brown, 2004, s. 178; tłum. - M.W.). Jednak często zdarza się, że wewnętrzne współzawodnictwo w firmie bierze górę nad priorytetami firmy, co wpływa na zakłócenie wewnętrznego dialogu, pomagającego w budowaniu świadomości, zrozumienia oraz akceptacji celów firmy.

Następnym czynnikiem, zakłócającym komunikację wewnętrzna firmy, jest nieświadomość tego, jak wyglądają stosunki komunikacyjne wśród pracowników. Z badań Hargiego i Tourisha (2000) wynika, że wśród pracowników najbardziej zaskoczonych wynikami audytów komunikacyjnych w firmach, odsłaniajaccymi problemy w sferze komunikacyjnej, są kierownicy wyższego szczebla. Swiadczy to o niezdawaniu sobie sprawy z, po pierwsze, stanu relacji komunikacyjnych wśród pracowników, po drugie $-\mathrm{z}$ wagi roli takiej komunikacji w rozwoju firmy, a po trzecie z faktu, że sama komunikacja jest niejednokrotnie odbiciem relacji ,podwładny - kierownik". Dlatego też kluczowym ogniwem w budowie efektywnego systemu komunikacji korporacyjnej jest skupienie się właśnie na zespole kierowniczym.

Tourish i Hargie (2004a, s. 132) wysuwają następujące założenia:

1) wszystkie organizacje potrzebują strategii komunikacyjnej, zaprojektowanej tak, aby stworzyć system podtrzymywania komunikacji wewnętrznej;

2) pierwszym krokiem do wdrożenia powyższego punktu jest zapewnienie drobiazgowej i uczciwej ewaluacji bieżącej praktyki komunikacyjnej, z wykorzystaniem technik audytu komunikacyjnego.

Pojęcie strategii komunikacyjnej można zdefiniować jako „proces, który umożliwia kierownikom ewaluację komunikacyjnych następstw procesu podejmowania decyzji i który włącza ją w cykl planowania biznesowego i mentalność organizacji” (tłum. M.W.) (Tourisch i Hargie, 2004a, s. 133; 1996, s. 12). Zgodnie z tym strategia komunikacyjna służy jako dogodne narzędzie w rękach kadry kierowniczej do tworzenia odpowiednich ram interakcji między pracownikami (por. Varey, 2002, s. 292) i poddania podejmowanych decyzji ocenie pod kątem właściwości komunikacyjnych, 
tzn. do sprawdzenia tego, jak proces decyzyjny wpływa na komunikację wewnętrzną w firmie, ale również służy ona wykorzystaniu takiej oceny w udoskonalaniu procesu planowania - także planowania komunikacji wewnętrznej.

Potrzeba tworzenia strategii komunikacyjnej (zob. rys. 1) wynika z faktu, że nie da się mówić o skutecznej komunikacji wewnątrz jakiejkolwiek organizacji, jeśli brakuje punktu odniesienia do jakichkolwiek ram komunikacji. Trudno bowiem wyobrazić sobie ocene komunikacji np. na torze podwładny - kierownik, gdy nie zostały postawione cele komunikacyjne, sprecyzowana wiadomość, dobrany kanał komunikacyjny i określony rezultat, efekt aktu komunikacji. Brak planowanej komunikacji prędzej czy później musi prowadzić do chaosu - zarówno informacyjnego, jak i organizacyjnego. Powodem tego jest nachodzenie na siebie kompetencji poszczególnych pracowników, którzy albo nie znają dostatecznie zakresu obowiązków i odpowiedzialności innych pracowników, albo, mając powierzone jakieś zadanie do wykonania w obrębie zespołu, nie skupiają się na swojej części, lecz na całości zadania projektowego. Ta niewiedza lub mylna ocena kompetencji wykonawczej wynika z zaburzeń przepływu informacji pomiędzy wspólpracownikami. Dlatego po to, by usunać te zaburzenia, nieodzowne jest stworzenie strategii komunikacyjnej, której wszyscy współpracownicy powinni być świadomi oraz powinni ją akceptować i traktować jako kluczowy element w realizacji zadań w firmie, bo zapewniający pracownikom swobodny, niezakłócony przepływ informacji.
Clampitt i Berk (2000) wskazują na pięć podstawowych zasad, które powinny organizować efektywny proces komunikacji wewnętrznej w firmie:

1) zespół kierowniczy pełni strategiczną funkcję w efektywnej komunikacji;

2) odpowiednie umiejętności komunikacyjne cechują pracowników wszystkich szczebli;

3) realizacja celów organizacyjnych jest uzależniona od odpowiedniej infrastruktury kanałów komunikacji;

4) realizacji celów organizacyjnych sprzyja właściwa polityka komunikacyjna i odpowiednie procedury;

5) informacja jest przekazywana w taki sposób, aby zostały zrealizowane cele organizacyjne.

Mówiąc oczywiście o celach organizacyjnych, mamy na myśli komunikację pomiędzy poszczególnymi pracownikami wszystkich szczebli w strukturze organizacyjnej firmy. $\mathrm{Z}$ zasad wymienionych powyżej wynika, że sama strategia komunikacyjna jest fenomenem o jasnej organizacji, w której istotną rolę odgrywają kompetencje (rola nadzorcza zespołu kierowniczego), predyspozycje do komunikacji jako takiej (umiejętności komunikacyjne), infrastruktura komunikacyjna, procedury i zasady korzystania z tej infrastruktury i - w końcu - relewancja wszystkich wymienionych wcześniej elementów co do celów; innymi słowy - przystawanie środków, kanałów i procedur komunikacyjnych do założonych celów, jakie mają być osiągnięte za przyczyną wdrożonej strategii komunikacyjnej.

Aby takowa strategia odniosła pożądany efekt, należy poddać ją krytycznej ocenie, weryfikacji, czemu m.in. służy audyt

Rysunek 1. Proces budowania komunikacji wewnętrznej firmy

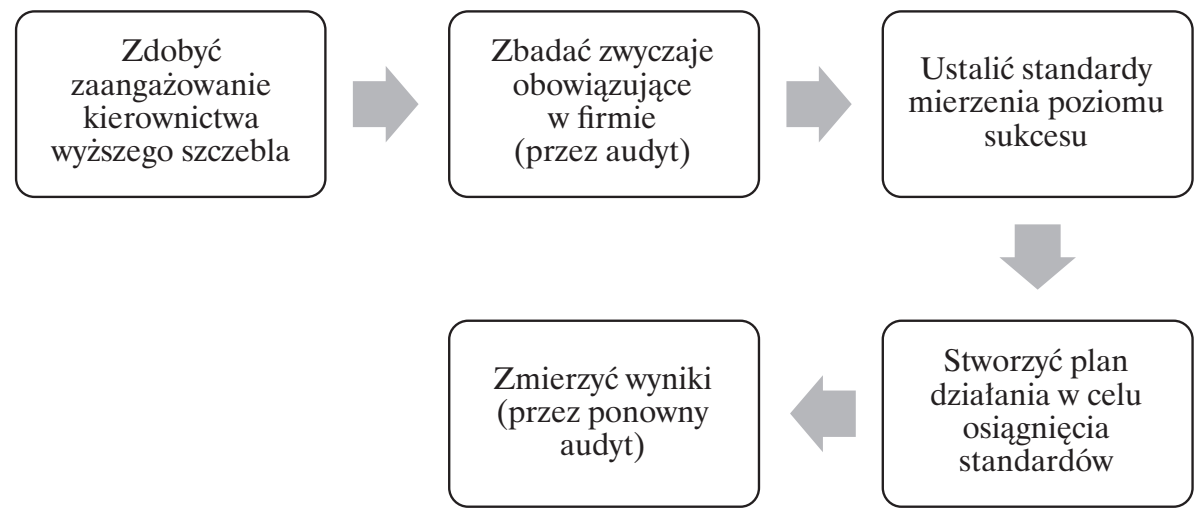

Źródło: opracowanie własne na podstawie badań Tourisha i Hargiego (2004b). 
komunikacyjny. Wspomnieliśmy wyżej, że warunkiem wstępnym efektywnej komunikacji w firmie jest przemyślana i dokładnie zaplanowana strategia komunikacyjna. Jednak jej wdrożenie nie oznacza automatycznego powodzenia komunikacyjnego, czego powodem może być albo niewłaściwe planowanie komunikacji, albo niedostateczny sposób wdrażania takiej strategii. Możliwość powstania obu tych wad jest przedmiotem audytu komunikacyjnego, podobnie jak opracowania środków naprawczych dla błędnie prowadzonej komunikacji.

\section{Pojęcie audytu komunikacyjnego}

Audyt komunikacyjny został zdefiniowany już w 1953 r. w pracy Davisa (1953) jako narzędzie rejestrowania i analizowania wzorców komunikacyjnych w organizacjach (Shelby, Reinsch i Lamar, 1996). Z kolei definicja audytu mówiąca, że: „audyt to nic więcej jak proces badania, zgłębiania, monitorowania lub ewaluacji czegoś. Księgowi audytują nasze sprawozdania finansowe, lekarze audytują stan naszego zdrowia, profesorowie audytują proces uczenia się, a kierownicy audytują poziom naszej efektywności. Innymi słowy, wszyscy mamy do czynienia $\mathrm{z}$ procesem audytowania” (Downs 1988, s. 3; tłum. M.W.) daje podstawe, by pojęcie audyt komunikacyjny wyeksplikować jako nic więcej niż proces badania, analizowania, monitorowania i oceniania wszelkich praktyk i zjawisk komunikacyjnych w jednostce (przedsiębiorstwie, organizacji czy instytucji), które badanie to obejmuje. Należy podkreślić, że praktyki i zjawiska komunikacyjne odnoszą się w tym przypadku do sfery komunikacji wewnętrznej, a nie do kompetencji językowych pracowników danej jednostki, bo wtedy można by mówić o audycie językowym (Alnajjar, 2013, s. 13).

Obrazując audyt komunikacyjny, Tourish i Hargie (2004b, s. 238) trafnie powołują się na metaforę kondycji fizycznej człowieka. Pod względem prawidłowego funkcjonowania poszczególnych organów audyt wykazuje te części firmy, które są zdrowe, ale również te, które cierpia na „organizacyjne nadciśnienie", w których miejscach rozrastają się „nowotwory niezadowolenia”, do jakiego stopnia są zapchane ,arterie komunikacyjne", a także diagnozuje obecny stan emocjonalnego i psychofizycznego samopoczucia całej firmy.
Audyt jest narzędziem, które powinno mierzyć zarówno znajomość struktury firmy, jej kultury, komunikacji, jak i poziom samorealizacji w niej (por. Grunig, 1992, s. 568). Te cztery aspekty winny być wyznacznikami sukcesu firmy. Naturalnie audytorzy nie moga sami - w drodze badania efektywności strategii komunikacyjnej - wpłynąć na wiedzę pracowników na polu tych aspektów, ale to oni powinni stać się motywatorami kierownictwa firmy do podjęcia starań do zmian w zakresie uświadamiania pracowników co do ww. aspektów. Ale podstawowym warunkiem tych zmian jest właśnie podjęcie szczerej i zorientowanej na konkretne cele komunikacji z nimi.

Audyt komunikacyjny jako narzędzie oceny efektywności komunikacji wewnętrznej w firmie ma wiele zalet. Audyt pozwala zidentyfikować mocne i słabe punkty strategii komunikacyjnej i przedstawić wyniki pracownikom, co jest motywującym ćwiczeniem i sprzyja rozwojowi konsultacji wewnętrznej (Furnham i Gunter, 1993, s. 204).

Audyt komunikacyjny daje pracownikom możliwość dokonania rewizji postrzegania komunikacji z innymi pracownikami. Dodatkowo daje on wgląd w stosunek bieżącej praktyki komunikacyjnej do realizacji celów. W przypadku zdefiniowania problemów komunikacyjnych audyt daje szanse na skorygowanie strategii komunikacyjnej i późniejsze jej zweryfikowanie, co prowadzi wyłącznie do rozwoju potencjału komunikacyjnego przedsiębiorstwa.

Hargie i Tourish (2000) zwracają uwagę na trzy elementy (fazy) wspólne wszelkim rodzajom audytów czy to mowa o audytach finansowych, medycznych, edukacyjnych, czy komunikacyjnych itp. (rys. 2).

W pierwszej fazie audytu zbierane są informacje nt. jakościowych i ilościowych aspektów komunikacji, które to dane przedstawiają obraz sieci kanałów informacji pomiędzy poszczególnymi działami firmy, a także w obrębie samych działów oraz obraz skuteczności wykorzystania tych kanałów przez pracowników.

Po zidentyfikowaniu deficytów w strategii komunikacyjnej nadchodzi faza naprawcza. W tym momencie należy stworzyć takie procedury i standardy, których przestrzeganie doprowadzi do wyeliminowania błędnych praktyk. W tym celu tworzony jest też system nadzorujący wdrażanie procedur naprawczych. 


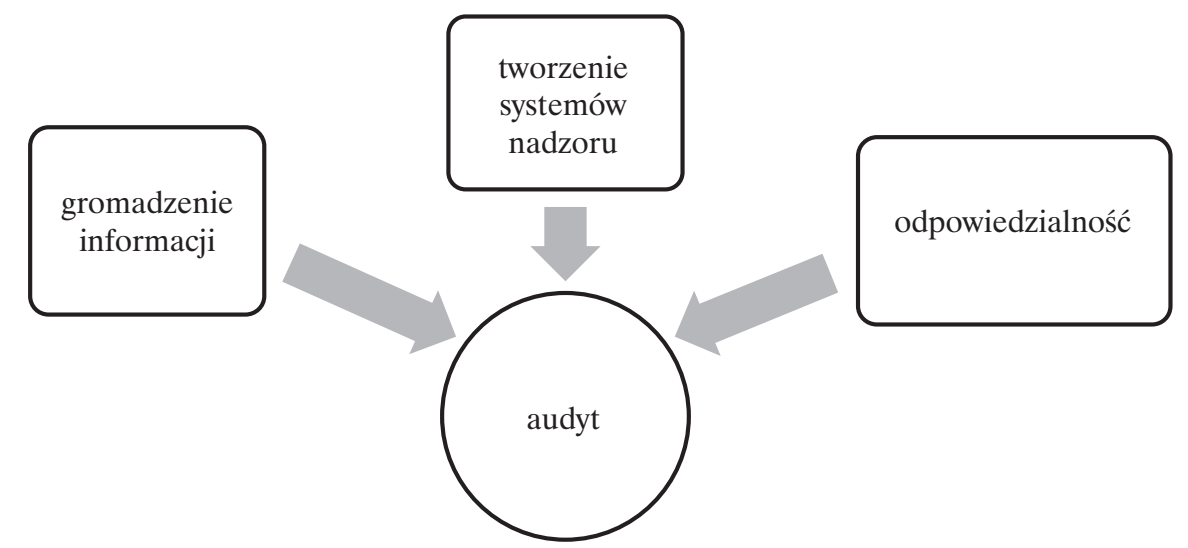

Źródło: opracowanie własne na podstawie badań Hargiego i Tourisha (2000).

Ostatnim elementem audytu jest odpowiedzialność i wynika on z fazy drugiej. Otóż jeśli tworzy się system nadzoru komunikacyjnego, należy wskazać ludzi odpowiedzialnych za poszczególne obszary strategii komunikacyjnej czy też komunikacji wewnętrznej w ogóle. Przypisywanie określonych zakresów odpowiedzialności za nadzór komunikacji jest o tyle pożądane, że pozwala szybko eliminować trudności komunikacyjne na każdym szczeblu i motywuje pracowników nadzorujących do ciągłego monitorowania przepływu informacji, tak więc uszczelnia system komunikacji.

Audyt komunikacyjny służy stworzeniu poglądu na strategię komunikacyjną, standardy i procedury do realizacji tej strategii, i ogólnie - na politykę komunikacyjną firmy, zorientowaną na zespół pracowników. Już same różnice w postrzeganiu efektywności komunikacji między zespołem kierowniczym a pracownikami niższego szczebla każą zastanowić się nad następującymi pytaniami:

- czy istnieją różnice w postrzeganiu hierarchii, struktury organizacyjnej firmy;

- jeśli takowe różnice istnieją, to jak się przekładają na procesy komunikacyjne pomiędzy poszczególnymi szczeblami hierarchii;

- w jaki sposób zlikwidować ewentualne, powyższe różnice, tzn. jak sprawić, aby postrzeganie struktury organizacyjnej i ważności płynnej komunikacji był zbieżny dla pracowników wyższego i niższego szczebla;

- w jaki sposób monitorować komunikację między zespołem kierowniczym a pozostałymi pracownikami $\mathrm{z}$ naciskiem na zapewnienie ciągłości skutecznej komu- nikacji i identyfikację powstałych błędów;

- jaki powinno się stworzyć system wdrażania procedur naprawczych, by rozpoznane błędy się nie powtórzyły?

\section{Procedura przeprowadzania audytu komunikacyjnego}

Trudno sobie wyobrazić, żeby jakiekolwiek zmiany mogły zajść na trwałe bez pełnej aprobaty i zaangażowania kierownictwa firmy. Dlatego nieodzowne jest zbudowanie u kierownictwa przekonania, że audyt komunikacyjny oferuje firmie zalety, które mogą przełożyć się na jakość komunikacji wewnętrznej między pracownikami, bezpośrednio na jakość ich pracy, kontakty z klientami i lepsze wyniki firmy w ogóle. Aby to przekonanie zbudować, należy przedstawić pracownikom wyższego szczebla również konsekwencje złej strategii komunikacyjnej i problemy, z jakimi w jej wyniku borykają się na co dzień pracownicy. Poza tym kontakt $\mathrm{z}$ kierownictwem jest nieodzowny do prawidłowego audytowania $\mathrm{w}$ tym sensie, że audytor powinien mieć możliwość stałego informowania kierownictwa o poszczególnych fazach audytu i jego postępach oraz mieć dostęp do informacji kluczowych dla prawidłowej ewaluacji strategii komunikacyjnej, tj. odnoszących się do polityki firmy, jej struktury organizacyjnej czy specyfiki pracy poszczególnych działów firmy.

Warto pamiętać, żeby zwrócić uwagę kierownictwa na kilka głównych problemów, które potencjalnie mogą pojawić się w komunikacji wewnętrznej, skupienie się bowiem na wielu aspektach komunikacji 
może po pierwsze zniechęcić kierownictwo do zaangażowania, a po drugie - nakreślenie ich może okazać się chybione, ponieważ mogą one w ogóle nie wystąpić.

Ważnym punktem spotkania z pracownikami wyższego szczebla na początku procedury audytowania jest zaproponowanie stworzenia standardów komunikacyjnych dla firmy - standardów, które kierownicy sami byliby chętni wprowadzić w życie. Brak świadomości potrzeby określenia standardów albo niejednoznaczność w rozumieniu tego, jak takie standardy komunikacyjne rozumieć, pokazują niektóre wypowiedzi z debaty z 2 lutego 2011 roku w formie okrągłego stołu w siedzibie „Polskiej Gazety Transportowej”, w której wzięli udział m.in. reprezentanci firm logistycznych i działów zarządzania informacją.

- H.B. (moderator dyskusji - M.W.): Wbranzy TSL nie ma jednoznacznej definicji standardów, również komunikacyjnych. Jak można je zdefiniować?

- E.H.: W GS1 wszystkie standardy rozumiemy jako pewne uzgodnienia, które strukturyzuja działalność branży oraz zasady dziatania usprawniające funkcjonowanie przedsiębiorstw. Za standardy komunikacyjne uważamy uzgodnione komunikaty $i$ ich format techniczny. Stuża one do wymiany zarówno informacji transakcyjnych, jak $i$ innych, np. o produktach, miejscu lub zdarzeniu realizowanym $w$ tańcuchu dostaw, $w$ ramach sieci EPC.

- P.S.: Uzupetnię to o schemat, bo ważny jest nie tylko zestaw, jaki wymieniamy, ale i przebieg dialogu - w jakiej kolejności kto wysyta komunikaty, jak potwierdza, czego ma się spodziewać $w$ odpowiedzi strona inicjujaca transakcje, jak powinna zareagować itd. Jest to schemat przeptywu danych opisany komunikatami na osi czasu.

- H.B.: Mówimy już o GS1, a ja chciałabym wrócić do standardów komunikacyjnych.

- G.C.: Komunikacja to nie tylko wymiana danych i plików. To także wymiana potrzeb, zapytań, opinii, komunikatów werbalnych itp. Oznacza to konieczność wtaściwego dobrania komunikatu, aby pozwolit on na zrozumienie się osób uczestniczacych $w$ procesie komunikacji. To również potwierdzenie, że informacja została zrozumiana $i$ odpowiedź na nia uczestników procesu wymiany oraz uzgodnienie $i$ potwierdzenie, że „tak będziemy się komunikowali”. Ma to dużo wspólnego $z$ wymiana danych, ale dotyczy wymiany informacji ogólnie („,Okragły Stół”/pgt.pl; emfaza - M.W.).

Kolejne trzy sposoby ujęcia standardu komunikacyjnego w powyższym fragmencie pokazują, że może on być rozumiany albo jako sama informacja (tu: komunikat + forma), albo jako transfer (proces nadania informacji i jej odbioru), albo w końcu holistycznie jako suma składowych aktu komunikacji, tzn. z wzięciem pod uwagę motywacji nadania komunikatu, intencji nadawcy, kodu, informacji zwrotnej co do właściwego - tj. zgodnego z intencją nadawcy - odbioru komunikatu, i uzgodnienie uzusu komunikacyjnego na przyszłość.

Tak rozumiany „transportowy model komunikacji" (zob. Keller, 2009, s. 22; Alnajjar, 2013, s. 11) mieści się w paradygmacie funkcjonalistycznym, który nie uwzględnia jej wymiaru kulturowego. Znaczenie jest w nim sprowadzone do przekaźnika informacji, która jest zapakowana i przesyłana $z$ jednego punktu do drugiego (Braman, 2004, s. 250), sam zaś akt komunikacji jest postrzegany jako droga, wzdłuż której następuje „przetransportowanie materiału wewnętrznego - informacji, którą wymieniają się aktorzy aktu komunikacji" (Varey, 2002, s. 25; (tłum. M.W.). Zgodnie $\mathrm{z}$ tym modelem wiedze traktuje się jako obiekt, który istnieje w oderwaniu od czynnika ludzkiego posiadania informacji, a przekazywanie informacji od nadawcy do odbiorcy jest pozbawione tego, co van Dijk nazywa „wspólnym tłem kulturowym” (2001, s. 15), które jest różnie profilowane w różnych grupach czy społecznościach, zgodnie z ich aksjologią i kulturą, w jakiej funkcjonuja (zob. Wilczewski, 2012, s. 43). Dzięki wspólnemu tłu kulturowemu, obejmującemu wspólną wiedzę, presupozycje i tło informacyjne, informacja nie jest już postrzegana jako coś niezmiennego, ale raczej jako kulturowo i społecznie uwarunkowany konstrukt, który służy za narzędzie do przekazywania intencji i osiągania celów komunikacyjnych.

Wspólne dla uczestników aktu komunikacji tło informacyjne oraz wiedza na temat tła kulturowego pozwala im zminimalizować niejasności w komunikacji. Znajomość tej wiedzy należy rozważać w kontekście interakcyjnej kompetencji uczestników komunikacyjnych, która polega na rozpoznawaniu ich kompetencji komunikacyjnej oraz różnic w tle informacyjnym. Kompetencja interakcyjna umożliwia im podjęcie w akcie komunikacji odpowiednich działań interakcyjnych (Łompieś, 2009, s. 176). Takie rozumienie komunikacji mieści się $\mathrm{w}$ nurcie humanistycznym w zarządzaniu, zgodnie z którym ,wszelka interakcja społeczna, a więc również wszelkie działania 
na polu organizacji i zarządzania, związana jest $\mathrm{z}$ aktywnym nadawaniem sensu (...) otaczającym nas zjawiskom, a zrozumienie procesów organizacyjnych musi wymagać poznania sieci symbolicznych znaczeń (...) przypisywanych owym procesom przez ich uczestników i przez obserwatorów. Znaczenia takie albo definicje wykonawcze, zawsze pozostają osadzone w szerszym kontekście kulturowym, a w komunikacji przybieraja nieodmiennie postać narracji” (Kociatkiewicz i Kostera, 2013, s. 3).

Sposobem na stworzenie standardów komunikacyjnych może być przyjęcie jakiegoś punktu odniesienia, czyli odwołanie się do efektywnych standardów już istniejących w innych firmach, organizacjach czy instytucjach. Budowanie standardów wymaga doboru odpowiednich kryteriów monitorowania komunikacji wewnętrznej i zewnętrznej przez kierownictwo wyższego szczebla, kryteriów szkolenia pracowników w zakresie komunikacji, zbierania danych i zarządzania nimi, zdefiniowania celów firmy, określenia poziomu wymagań jakościowych w zakresie komunikacji i zaangażowania kadry pracowniczej $\mathrm{w}$ realizację tych standardów (por. Horton, 1995, s. 272). O ważności standardów komunikacyjnych świadczy fakt, że np. prezydent USA przyznaje corocznie firmom amerykańskim ustanowiona przez Kongres w 1987 roku Nagrodę im. Malcolma Baldrige'a (Malcolm Baldrige National Quality Award) za osiagnnięcia w zarządzaniu jakością (Avery i Zabel, 1997, s. 299), obejmującą - obok innych kluczowych elementów - pomiar, analizę i zarządzanie wiedzą (zarządzanie danymi, dostęp pracowników do informacji, pomiar jakości informacji).

Informacja o planowanym audycie powinna zostać zakomunikowana przez pracownika możliwie najwyższego szczebla w firmie, najlepiej od dyrektora głównego czy samego prezesa firmy, czyli kogoś, kto cieszy się w firmie największym autorytetem. Dzięki temu pracownicy i kierownicy będą czuć się zobligowani do zaangażowania się w audyt, gdyż uczestnictwo w nim będą traktować jako obowiązek służbowy. Zeby zaś uczestnicy audytu potraktowali ten obowiązek poważnie i udzielali audytorom szczerych odpowiedzi, Tourish i Hargie (2004a, s. 137) proponują zastosowanie się do pięciu punktów, które wypracowali w drodze przeprowadzonych kilku audytów komunikacyjnych:
1. Należy zapewnić uczestników audytu, zarówno w formie ustnej, jak i pisemnej, że wszystkie ich odpowiedzi i wypowiedzi będą poufne. Dzięki temu można uniknąć nieszczerych odpowiedzi, spowodowanych obawą przed konsekwencjami ze strony kierownictwa.

2. Uczestnicy audytu powinni być wybierani losowo. Losowanie pracowników do wypełniania kwestionariuszy ma na celu maksymalne zobiektywizowanie wyników audytu i uniknięcie sytuacji, w której pracownicy odnosiliby wrażenie, że są monitorowani przez przełożonych.

3. Do materiałów badawczych, takich jak kwestionariusze, ankiety, nagrania czy jakichkolwiek materiałów zawierających dane osobowe respondentów, dostęp powinni mieć tylko członkowie zespołu audytującego. Po zakończeniu audytu materiały takie powinny zostać zniszczone, żeby kierownictwo i pozostali pracownicy nie mieli w przyszłości możliwości wglądu do odpowiedzi konkretnych respondentów.

4. W końcowym raporcie należy podjąć szczególne starania, aby przez nieuwagę nie ujawnić tożsamości respondentów. Taka sytuacja może mieć miejsce wtedy, gdy przytaczany jest komentarz pochodzący od pracownika z konkretnego stanowiska badź jednoosobowego działu.

5. Kolejne fazy audytu powinny być wdrażane $\mathrm{z}$ dala od naocznego nadzoru kierownictwa. Jest tak dlatego, że respondenci w jakikolwiek sposób związani $\mathrm{z}$ przełożonymi mogą nie chcieć $\mathrm{w}$ ich obecności udzielać szczerych odpowiedzi, co wpływa na obniżenie wiarygodności całego audytu. Poza tym proponuje się, by audyt przeprowadzały osoby „,z zewnątrz”, a nie pracownicy firmy, dzięki czemu można uniknąć powyższego problemu.

Pierwszym etapem zbierania danych w drodze audytu komunikacyjnego jest opracowanie lub wykorzystanie istniejącej metody badawczej, która umożliwi pozyskanie informacji dotyczących następujących kwestii:

- znajomość struktury organizacyjnej firmy; można tu np. poprosić respondenta o podanie schematu organizacyjnego firmy, dzięki czemu będzie możliwe ocenienie znajomości hierarchii zawodowej, ważnej z punktu widzenia przepływu informacji; 
- znajomość strategii komunikacyjnej; należy postawić pytania o obecną strategię czy takowa w ogóle istnieje, czy jest respondentowi znana;

- infrastruktura komunikacyjna; jakie sa kanały komunikacji, zalety i wady takiej infrastruktury;

- trudności w komunikacji między pracownikami.

Drugim etapem zbierania danych jest weryfikacja ułożonych pytań poprzez test pilotażowy, przeprowadzony na kilku losowo wybranych pracownikach. Jest to moment, gdy można jeszcze na podstawie otrzymanych odpowiedzi ustalić czy pytania audytorów są zrozumiale sformułowane, czy nie są sugestywne albo czy respondenci z jakichś powodów nie udzielają odpowiedzi na konkretne pytania (dzięki temu można je uzupełnić bądź przeformułować).

Kolejnym krokiem w procedurze audytowania jest analiza zebranych danych, której rezultatem powinno być wyciągnięcie wniosków co do kroków, jakie należy podjąć, by poprawić komunikację wewnętrzną. W odniesieniu do zasygnalizowanych wyżej czterech kwestii problemowych byłyby to wnioski dotyczące:

- uzupełnienia wiedzy nt. struktury organizacyjnej, zakresu działalności poszczególnych działów firmy i nt. innych informacji kluczowych dla funkcjonowania firmy i komunikacji wewnętrznej;

- uzupełnienia wiedzy nt. istniejącej strategii komunikacyjnej; jeżeli strategia ma jakieś błędy i słabe punkty, należy je usunąć, a zaktualizowaną strategię przedstawić pracownikom;

- uzupełnienia wiedzy nt. poprawnego korzystania z infrastruktury komunikacyjnej; w przypadku błędnego doboru (nieefektywnych) kanałów komunikacji należy infrastrukturę zrewidować bądź zaplanować na nowo;

- podjęcia kroków w celu pokonania trudności w komunikacji między pracownikami; w tym miejscu można wskazać osoby odpowiedzialne za przepływ informacji na poszczególnych poziomach.

\section{Metody przeprowadzania audytu komunikacyjnego}

W zależności od rodzaju firmy można zastosować różne metody do zbadania prawidłowego stanu komunikacji wewnętrznej. Audytorzy mają do dyspozycji takie narzę- dzia, jak kwestionariusz ankiety, wywiad, grupa fokusowa (focus group), analiza sieciowa (network analysis; analiza stosunków między elementami badanej sieci) czy analiza zdarzeń krytycznych (critical incident analysis) (Shelby et al., 1996), a także dzienniki komunikacyjne, mapowanie $\mathrm{i}$ analiza sieci komunikacyjnych (ECCO - 'Episodic Communication Channels in Organization'), Mystery Shopper (tajny klient), nagrania wideo, opis gęsty, metoda delficka czy obserwacja uczestnicząca (zob. Winkler, 2011, s. 244-245).

Ze względu na łatwość opracowywania i odczytywania wyników najpopularniejszą metodą audytu komunikacyjnego jest kwestionariusz ankiety, którego niewątpliwą zaletą jest to, że można korzystać Z gotowych wzorów, fachowo opracowanych w drodze realizacji kilku audytów; zob. np. Grunig, Grunig i Dozier (2002). Kwestionariusz jest o tyle wygodnym narzędziem, że zebrane wyniki można w prosty sposób przedstawić w formie danych statystycznych i wykorzystać w przyszłości jako punkt odniesienia w trakcie audytu kontrolnego. Poza tym można go przeprowadzić na dowolnej liczbie pracowników, nie poświęcając na badanie wielkich nakładów finansowych i dużej ilości czasu. Niemniej trzeba mieć na uwadze fakt, że kwestionariusz ankiety jako indywidualnie stosowane narzędzie badawcze ma swoje wady, a mianowicie jest przykładem ilościowego podejścia do badania tak ,płynnego” zjawiska kulturowego, jakim jest komunikacja.

Metodą jakościową, wykorzystywaną w badaniu komunikacji wewnętrznej, jak i zewnętrznej, jest wywiad. Jest ona o tyle korzystna, że w drodze wywiadu badacz może poznać informacje, których nie sposób wychwycić w kwestionariuszu ankiety. Wywiad pozwala zatem na głębszy wgląd w sposób postrzegania i interpretowania działań organizacyjnych przez pracowników. Niewątpliwie sprzyja temu społeczny charakter takiej formy zbierania informacji, bo wywiad narzuca dwukanałową interakcję (osadzoną w konkretnym kontekście i mającą konkretne cele) pomiędzy osobą go przeprowadzającą a ankietowanym. Każda strona tej interakcji kieruje względem strony przeciwnej konkretne oczekiwania, a także wyraża chęć współpracy (Millar i Gallagher, 2000, s. 66). Nie bez przyczyny wywiad wciąż pozostaje najpopularniejszym narzędziem stosowanym 
w procesie rekrutacji (np. pracowników, studentów), jako że aspekt społeczny jest kluczowy przy podejmowaniu tego typu decyzji. Ze względu na pracochłonność, a co za tym idzie - względnie wysokie koszty tej metody, wywiad można efektywnie wykorzystać w formie uzupełnienia kwestionariusza, np. przez ograniczenie respondentów do kierownictwa albo przeprowadzenia wywiadu dopiero po analizie danych z kwestionariuszy, tak aby doprecyzować pewne kwestie lub rozwiać ewentualne wątpliwości.

Następną metodą jakościową, prowadzącą do zrozumienia określonych zachowań i wyjaśniania ich w specyficznym kontekście (Reinard, 2001, s. 223), jest praca w tzw. grupach fokusowych (focus groups), która polega na prowadzeniu dyskusji Z grupą pracowników (przeważnie 6-12 osób), konfrontowaniu ich opinii na dany temat i poznawaniu ich potrzeb informacyjnych. Obecnie jednak grupy fokusowe staja sie coraz powszechniejszą metoda jakościową w badaniach akademickich, a zwłaszcza w takich obszarach nauk społecznych, jak ocena programu (program evaluation), polityka publiczna, praca $\mathrm{w}$ opiece społecznej, opieka zdrowotna, komunikacja, ale także nauki o rodzinie czy terapia rodzinna (Piercy i Hertlein, 2005, s. 86).

Praca w grupie fokusowej polega na prowadzeniu dyskusji z grupą pracowników na tematy poruszane np. w ankietach. Zaletą tego typu dyskusji jest to, że członkowie grupy na bieżąco rozwijają omawiane tematy, więc zebrane dane dotyczą obszarów, które w ankietach mogą być w ogóle niepodejmowane. $\mathrm{Z}$ założenia grupa fokusowa ma dać możliwość nawiązania interakcji pomiędzy uczestnikami, bo wyzwala i napędza dyskusję oraz wymianę poglądów - dostarcza więc w praktyce cenniejszych danych, których często nie da się zebrać w wywiadzie indywidualnym czy w ankietach (Gratton i Jones, 2003, s. 155). Jednak metoda ta ma też swoje wady. Otóż trudno ją efektywnie wykorzystać $\mathrm{w}$ przypadku pracowników o introwertycznej osobowości albo tych, którzy obawiają się o niezachowanie pełnej poufności (w grupie ten warunek nie może być spełniony).

Jeśli chodzi o procedury przeprowadzania audytu komunikacyjnego, to w latach siedemdziesiątych ubiegłego wieku wypracowano trzy zasadnicze standardy (Wiio, Goldhaber i Yates, 1980, s. 84):
1. ICA (International Communication Association Communication Audit) standard wypracowany w 1971 roku przez Międzynarodowe Towarzystwo Komunikologiczne,

2. LTT (Liiketaloustieteellisen Tutkimuslaitoksen Communication Audit Procedure) - procedura wypracowana w latach 1971-1974 przez Helsinki Research Institute for Business Economics,

3. OCD (Organizational Communication Development) - standard stworzony w latach 1976-1977 przez Osmo A. Wiio, współtwórcę (obok Martti Helsilä) procedury LTT.

Standard ICA jest najbardziej złożoną procedurą, wykorzystującą $w$ audycie takie metody, jak: kwestionariusz ankiety, wywiad bezpośredni, analize sieci powiązań komunikacyjnych, analizę zdarzeń krytycznych i rejestr zdarzeń komunikacyjnych. Procedury LTT i OCD wykorzystywały jedynie kwestionariusz ankiety, gdzie w przypadku LTT pytania odnosiły się do takich zagadnień, jak: dostęp pracowników do informacji, jakość informacji, aktywność komunikacyjna pracowników i ich satysfakcja $\mathrm{z}$ pracy, doskonalenie komunikacyjne i czynniki klimatu organizacji, natomiast w przypadku OCD - zapotrzebowanie na informację i dostęp do niej, efektywność kanałów komunikacyjnych, przyczyny wadliwej komunikacji, doskonalenie komunikacji i satysfakcja pracowników z pracy (Winkler, 2010, s. 120; 2011, s. 242).

Doświadczenia związane z wdrażaniem tych wysoce standaryzowanych procedur pokazały, że w badaniu komunikacji wewnętrznej nie da się zastosować jednego, uniwersalnego szablonu. Jak pisze Winkler (2010, s. 121): „Każdorazowo dla danej organizacji, czy to $\mathrm{w}$ odniesieniu do komunikacji wewnętrznej, czy zewnętrznej, należy zaprojektować audyt komunikacyjny „na miarę". Jest to warunkowane głównie specyfiką samego procesu komunikowania się międzyludzkiego, który nie tylko nie podlega w bezpośredni sposób kwantyfikacji, ale trudno też $\mathrm{w}$ odniesieniu do niego opracować jednoznaczne i sztywne procedury. Nie można również postawić znaku równości między procesem komunikacji a diagnozowanymi przepływami różnego typu wiadomości i informacji w obrębie organizacji (...). W odniesieniu do komunikacji wewnętrznej, znajduje to uzasadnienie w tym większym stopniu, że chociaż proces 
ten w obrębie organizacji zdeterminowany jest przez system organizacji, w obrębie którego jest realizowany, to zakres obecnych i perspektywicznych potrzeb komunikacyjnych zatrudnionych $\mathrm{w}$ organizacji podmiotów nie zależy wyłącznie od zakresu przyporządkowanych im zadań”.

\section{Implikacje wynikające $z$ audytu komunikacyjnego}

Każdy audyt komunikacyjny jest specyficzny, tak jak nie istnieją dwie identyczne firmy czy organizacje. Dlatego też każdy audyt powinien być planowany indywidualnie, zgodnie z potrzebami danej firmy. Wyniki audytów są także różne, ponieważ są opracowywane na różnych danych i w obrębie różnych obszarów problemowych. Tourish i Hargie (2004b) na podstawie przeglądu literatury przedmiotu oraz własnych badań opracowali najczęściej pojawiające się wnioski, uzyskane w drodze audytu komunikacyjnego:

1. Kluczową w komunikacji pomiędzy kierownictwem a pracownikami jest osoba bezpośredniego przełożonego, który powinien się interesować każdym z podwładnych, wsłuchiwać się w ich opinie, szybko i zdecydowanie reagować na problemy, regularnie informować pracowników nt. bieżącej pracy i tego, co się dzieje w firmie, a także organizować zebrania, na których wszyscy mieliby szansę wypowiedzieć się.

2. Należy rozwijać komunikację oddolną, polegającą na tym, że pracownicy niższego szczebla mają możliwość wyrażania opinii swoim przełożonym, zawsze moga liczyć na informację zwrotną i mają poczucie, że ich uwagi są doceniane. W ten sposób u pracownika wzrasta poczucie identyfikacji z firmą, dzięki czemu jest bardziej skłonny informować o swoich odczuciach, a co za tym idzie chętniej bierze aktywny udział w komunikacji wewnętrznej firmy.

3. Informacja powinna być szeroko rozpowszechniana $\mathrm{w}$ obrębie firmy. Jednym $\mathrm{z}$ celów audytu jest monitorowanie poziomu przepływu informacji, który jest kluczowy dla efektywnego funkcjonowania firmy.

4. Kierownicy powinni jak najczęściej korzystać w kontaktach z podwładnymi $\mathrm{z}$ komunikacji twarzą w twarz. Bez takiego kontaktu trudno bowiem zreali- zować punkt 1, w którym kluczowe było budowanie indywidualnej relacji z pracownikiem.

5. Ważną rolę $\mathrm{w}$ poprawie komunikacji wewnętrznej odgrywają szkolenia pracownicze. Oprócz oczywistej zalety, jaką jest poprawa komunikacji, tego typu szkolenia niewątpliwie poprawiają umiejętności związane z kierowaniem ludźmi, więc przyczyniają się do polepszenia jakości pracy.

\section{Podsumowanie}

W artykule starano się przedstawić, jak ważna jest strategia komunikacyjna dla prawidłowego przepływu informacji w firmie. Należy zdać sobie sprawę z tego, że jeśli nie jest ona przemyślana i regularnie oceniana, to tak naprawdę nie można mówić o jakiejkolwiek strategii, a taka sytuacja prędzej czy później prowadzi do zakłóceń w komunikacji i osłabienia współpracy wewnątrz firmy.

Audyt komunikacyjny jest dogodnym narzędziem do diagnozowania bieżącego stanu i polityki komunikacyjnej. Dzięki niemu pracownicy mają dogodną okazję do uzupełnienia wiedzy nt. organizacji i funkcjonowania swojej firmy, kompetencji współpracowników i infrastruktury komunikacyjnej, a także do rozwinięcia własnych umiejętności komunikacyjnych na rzecz lepszej współpracy i efektywniejszej realizacji celów firmy. Trudno sobie bowiem wyobrazić dobrze prosperującą firmę czy jakąkolwiek organizację, w której procesy komunikacyjne byłyby zaburzone przez nieznajomość organizacji tej firmy i poprawnego korzystania z kanałów komunikacji w celu osiągnięcia określonych celów, czyli przez niestosowanie się do strategii komunikacyjnej.

Audyt komunikacyjny jest idealnym sposobem na monitorowanie postępów w komunikacji wewnętrznej. Oferuje on metody badania oczekiwań i oglądu komunikacji wewnętrznej przez kierownictwo i pracowników niższego szczebla. Poza tym zdaje relację z postępów osób odpowiedzialnych za nadzór nad konkretnymi obszarami przepływu informacji, daje możliwość wyciagnięcia wniosków i podania gotowych recept na skorygowanie strategii komunikacyjnej, co ostatecznie wpływa na polepszenie efektywności, komfortu pracy i motywacji pracowników (szybszy przepływ informacji, unikanie sytuacji problemowych). 
Do wdrażania decyzji niezbędny jest efektywny, strategiczny plan komunikacyjny firmy, organizacji, który powinien integrować $\mathrm{z}$ sobą proces badania, planowania, komunikacji i ewaluacji. Jest to niezbędne po to, aby priorytety firmy, wszystkie decyzje podjęte przez zarząd nie zginęły gdzieś pod nawałem informacji w codziennej komunikacji. Poza tym strategia komunikacyjna wyznacza potrzebę oceny efektywności jej wdrażania, więc automatycznie staje się narzędziem (i niejako wymusza konieczność) ewaluacji postępu realizacji planu komunikacyjnego.

\section{Bibliografia}

Alnajjar, J. (2013). Audyt komunikacyjny w przedsiębiorstwie - nowy przedmiot zainteresowania lingwistyki. Lingwistyka Stosowana/Applied Linguistics/ Angewandte Linguistik, 8, 7-26.

Avery, Ch. i Zabel, D. (1997). The Quality Management Sourcebook: An International Guide to Materials and Resources. London: Routledge, http:// dx.doi.org/10.4324/9780203298008.

Balmer, J.M.T. i Gray, E.R. (2000). Corporate Identity and Corporate Communications: Creating a Competitive Advantage. Industrial and Commercial Training, 32(7), 256-262, http://dx.doi. org/10.1108/00197850010379811.

Bovée, C. L. i Thiel, J.V. (2000). Business Communication Today. Upper Saddle River, NJ.: Prentice Hall.

Braman, S. (2004). Biotechnology and Communication: The Meta-Technologies of Information. Mahwah, NJ: Lawrence Erlbaum Asscociates, Inc.

Brun, M. (2002). Creating a new identity for France Télécom: beyond a visual exercise?. W: B. Moingeon i G. Soenen (red.), Corporate and Organizational Identities: Integrating Strategy, Marketing, Communication, and Organizational Perspectives. London: Routledge.

Cheney, G. i Christensen, L. (2001). Organizational Identity Linkages Between Internal and External Communication. W: F.M. Jablin i L.L. Putnam (red.), The New Handbook of Organizational Communication. Thousand Oaks: Sage, 231-269, http:// dx.doi.org/10.4135/9781412986243.

Clampitt, P.G. i Berk, L. (2000). A Communication Audit of a Paper Mill. W: O. Hargie i D. Tourish (red.), Handbook of Communication Audits For Organisations. London: Routledge.

Clampitt, P.G. i Downs, W. (1993). Employee Perceptions of the Relationship. Between Communication and Productivity: A Field Study. Journal of Business Communication, 30(1), 5-28, http://dx.doi. org/10.1177/002194369303000101.
Clampitt, P.G., DeKoch, R. i Cashman, T. (2000). A Strategy for Communicating about Uncertainty. Academy of Management Executive, 14(4), 41-57, http://dx.doi.org/10.5465/AME.2000.3979815.

Cornelissen, J. (2004). Corporate Communications: Theory and Practice. London: Sage Publications.

Davis, K. (1953). A Method of Studying Communication Patterns in Organizations. Personnel Psychology, 6(3), 301-312, http://dx.doi. org/10.1111/j.1744-6570.1953.tb01499.x.

Deetz, S. i Brown, D. (2004). Conceptualizing involvement, participation and workplace decision processes: A communication theory perspective. W: D. Tourish i O. Hargie (red.), Key Issues in Organizational Communication. London: Routledge.

Dijk van, T.A. (2001). Discourse, Ideology and Context. W: W.U. Dressler (red.), Folia Linguistica $X X X V / 1-2$. Berlin: Mouton de Gruyter.

Downs, C.W. (1988). Communication Audits. Glenview, IL: Scott Foresman.

Dunmore, M. (2002). Inside-out Marketing: How to Create an Internal Marketing Strategy. London: Kogan Page Limited.

Furnham, A. i Gunter, B. (1993). Corporate culture: definition, diagnosis and change. W: C.L. Cooper i I.T. Robertson (red.), International Review of Organizational Psychology, Vol. 8. West Sussex: John Wiley \& Sons.

Gratton, Ch. i Jones, I. (2003). Research Methods for Sport Studies. New York: Routledge.

Gray, E.R. i Balmer, J.M.T. (1998). Managing Corporate Image and Corporate Reputation. Long Range Planning, 31(5), 695-702, http://dx.doi. org/10.1016/S0024-6301(98)00074-0.

Gros, U. (2003). Zachowania organizacyjne w teorii i praktyce. Warszawa: PWN.

Grucza, S. (2013). Lingwistyka języków specjalistycznych. Warszawa: Wydawnictwo Naukowe Instytutu Kulturologii i Lingwistyki Antropocentrycznej UW.

Grunig, J.E. (1992). Symmetrical Systems of Internal Communication. W: J.E. Grunig, D.M. Dozier, W.P. Ehling, L.A. Grunig, F.C. Repper i J. White (red.), Excellence in Public Relations and Communication Management. Hillsdale, NJ: Lawrence Erlbaum Associates.

Grunig, L.A., Grunig, J.E i Dozier, D.M. (2002). Excellent Public Relations and Effective Organizations: A Study of Communication Management in Three Countries. Mahwah, NJ: Lawrence Erlbaum Associates.

Hargie, O. i Tourish, D. (red.) (2000). Handbook of Communication Audits For Organisations. London: Routledge.

Holtz, Sh. (2004). Corporate Conversations: A Guide to Crafting Effective and Appropriate Internal Communications. New York: AMACOM. 
Horton, J.L. (1995). Integrating Corporate Communications: The Cost-Effective Use of Message and Medium. Westport, CT: Quorum Books.

Jung-Konstanty, S. (2013). Theories and principles of organizational communication in public schools. Wspótczesne Zarzadzanie, 2, 169-179.

Keller, R. (2009). Die Sprache der Geschäftsberichte: Was das Kommunikations-verhalten eines Unternehmens über dessen Geist aussagt. W: Ch. Moss (red.), Die Sprache der Wirtschaft. Wiesbaden: Westdeutscher Verlag.

Kociatkiewicz, J. i Kostera, M. (2013). Zarządzanie humanistyczne. Zarys programu. Problemy Zarzadzania, 4(44), 9-19, http://dx.doi.org/10.7172/16449584.44.1.

Łompieś, J.B. (2009). Bariery i zakłócenia w procesie «business communication» - część II. Komunikacja Specjalistyczna, 2, 166-179.

Łompieś, J.B. (2014). Raport spótki gietdowej. Studium pragmalingwistyczne. Warszawa: Wydawnictwo Naukowe Instytutu Kulturologii i Lingwistyki Antropocentrycznej UW.

Mazzei, A. (2010). Promoting Active Communication Behaviours Through Internal Communication. Corporate Communications: An International Journal, 15(3), 221-234, http://dx.doi. org/10.1108/13563281011068096.

Millar, R. i Gallagher, M. (2000). The Interview Approach. W: O. Hargie i D. Tourish (red.), Handbook of Communication Audits For Organisations. London: Routledge.

Ober, J. (2013). Funkcja i rola efektywnej komunikacji w zarządzaniu. Zeszyty Naukowe Politechniki Ślaskiej. Organizacja i Zarządzanie, 65, 257-266,

„Okrągły Stół”/pgt.pl. (2011). Pobrano z http://pgt. $\mathrm{pl} /$ index.php?option $=$ com_content $\&$ task $=$ view \&i$\mathrm{d}=1475 \&$ Itemid $=41(17.0 \overline{1} .2014)$.

Olsztyńska, A. (2002). Komunikacja wewnętrzna w przedsiębiorstwie. W: H. Mruk (red.), Komunikowanie się w biznesie. Poznań: Wydawnictwo Akademii Ekonomicznej.

Piercy, F.P. i Hertlein, K.M. (2005). Focus Groups in Family Therapy Research. W: D.H. Sprenkle i F.P. Piercy (red.), Research Methods in Family Therapy. New York: Guilford Press.

Quirke, B. (2008). Making the Connections: Using Internal Communication to Turn Strategy Into Action. Hampshire: Gower Publishing Limited,

Reinard, J.C. (2001). Introduction to Communication Research (3 ${ }^{\text {rd }}$ Edition). New York: McGraw-Hill.

Rekon van, J. (2002). Manifestations in behavior versus perceptions of identity: convergence or not? W: B. Moingeon i G. Soenen (red.), Corporate and Organizational Identities: Integrating Strategy, Marketing, Communication, and Organizational Perspectives. London: Routledge.
Rogala, A. i Kaniewska-Sęba, A. (2013). Internal communication as a marketing communication's tool. W: J.C. Andreani i U. Collesei (red.), 12th International Marketing Trends Conference: Proceedings (s. 1-21). Paris: European School of Management.

Scholes, E. (red.) (1997). Gower Handbook of Internal Communication. Hampshire: Gower Publishing Limited.

Shelby, A.N., Reinsch, N. i Lamar, J.R., (1996). The Communication Audit: A Framework for Teaching Management Communication. Business Communication Quarterly, 59(2), 95-108, http:// dx.doi.org/10.1177/108056999605900208.

Tourish, D. i Hargie, O. (1996). Internal Communication: Key Steps in Evaluating and Improving Performance. Corporate Communications: An International Journal, 1(3), 11-16, http://dx.doi. org/10.1108/eb059593.

Tourish, D. i Hargie, O. (2004a). Communication Audits: Building World Class Communication Systems. W: S.M. Oliver (red.), Handbook of Corporate Communication and Public Relations: Pure and Applied (s. 131-144). London: Routledge, http:// dx.doi.org/10.4324/9780203414958.pt2.

Tourish, D. i Hargie, O. (2004b). How are we doing? Measuring and monitoring organizational communication. W tychże: Key Issues in Organizational Communication. London: Routledge.

Van Riel, C.B.M. (1995). Principles of Corporate Communication., London: Prentice Hall.

Van Riel, C.B.M. (2003). The Management of Corporate Communication. W: J.M.T. Balmer i S.A. Greyser (red.), Revealing the Corporation: Perspectives on Identity, Image, Reputation, Corporate Branding, and Corporate-Level Marketing: An Anthology. London: Routledge.

Varey, R.J. (2002). Marketing Communication: Principles and Practice, London: Routledge.

Wiio, O.A., Goldhaber, G.M. i Yates, M.P. (1980). Organizational Communication Research: Time for Reflection? W: D. Nimmo (red.), Communication Yearbook, 4. New Brunswick, NJ: Transaction Books.

Wilczewski, M. (2012). Sposoby profilowania konfliktów zbrojnych $w$ wybranych polskich $i$ amerykańskich tekstach prasowych (na przykładzie operacji „Odyssey Dawn” w Libii). Olsztyn: Centrum Badań Europy Wschodniej UW-M.

Winkler, R. (2010). Audyt komunikacyjny - wymiar wewnętrzny. W: A. Stabryła (red.), Systemy controllingu, monitoringu i audytu. Kraków: Encyklopedia Zarządzania.

Winkler, R. (2011). Audyt komunikacji wewnętrznej. W: A. Potocki, R. Winkler, R. i A. Żbikowska (red.), Komunikowanie $w$ organizacjach gospodarczych. Warszawa: Difin. 